\title{
IMPLEMENTASI LESSON STUDY SEBAGAI UPAYA MENINGKATKAN PARTISIPASI AKTIF SISWA DALAM PEMBELAJARAN VIRTUAL
}

\author{
Rika Rahmadani Putri ${ }^{1}$, Nova Susanti ${ }^{*}$ \\ ${ }^{1}$ SMP Al Falah Jambi, ${ }^{2}$ Pendidikan Fisika Universitas Jambi \\ *Email: nova_fisikaunja@unja.ac.id
}

\begin{abstract}
The outbreak of Covid-19 has resulted in learning activities to be carried out virtually. Based on the experience of implementing virtual learning, students do not participate actively in the learning process. Low student participation in education can be seen from the lack of student responses in answering teacher questions in virtual learning. Based on this problem, the authors researched by implementing lesson study as an effort to increase students' active participation in virtual learning. This study aims to increase students' active involvement in virtual education through the implementation of lesson study. The subjects of this research were 32 students of Al Falah Islamic Junior High School class VIII.5 semester 2020/2021 academic year with 13 male students and 19 female students. Implementation of lesson study starts on August 18 to September 1, 2020. This type of research is qualitative research. Data collection was carried out through student active participation observation sheets. Based on the research results in cycle 1, student participation data obtained an average value of $56.28 \%$. While in cycle 2, the student participation data received an average value of $59.56 \%$.
\end{abstract}

Key word: Lesson Study, Student Active Participation, Virtual Learning

\section{PENDAHULUAN}

Dewasa ini, dunia digemparkan dengan virus yang dikenal dengan istilah Covid-19. who.int menjelaskan dalam websitenya di bagian News bahwa covid-19 (coronavirus disease 2019) adalah jenis penyakit yang disebabkan oleh virus dari golongan coronavirus, yaitu SARS-CoV-2 yang juga sering disebut virus Corona. Covid-19 dapat menyebar melalui percikan-percikan dari hidung atau mulut yang keluar saat orang yang terinfeksi Covid-19 batuk, bersin atau berbicara. Orang lain dapat terinfeksi covid-19 jika menghirup percikan dari orang yang terinfeksi virus ini. Sehingga kita perlu menjaga jarak dengan orang lain minimal 1 meter.
Mewabahnya covid-19 ini menyebabkan pembelajaran tatap muka di sekolah ditiadakan, sehingga proses pembelajaran dilaksanakan secara daring. Ada beberapa hal yang menjadi kendala dalam proses pembelajaran daring, diantaranya adalah sulitnya akses jaringan di beberapa daerah, faktor ekonomi yang membuat siswa sulit untuk membeli kuota, dan sering terputusnya aliran listrik. Berdasarkan pengalaman melaksanakan pembelajaran virtual siswa kurang berpatisipsi aktif dalam proses pembelajaran. Rendahnya partisipasi siswa dalam pmbelajaran terlihat dari sedikitnya respon siswa dalam menjawab pertanyaan guru pada pembelajaran virtual. Peserta didik cenderung diam mendengarkan, dari 
pada aktif menjawab pertanyaan guru dalam proses pembelajaran. Hal ini menjadi tantangan bagi pendidik untuk merancang strategi pembelajaran yang dapat memfasilitasi peserta didik memahami pembelajaran dan dapat berpartisipasi aktif dalam proses pembelajaran sehingga pembelajaran berpusat pada peserta didik (student centerd).

Pembelajaran berpusat pada siswa (student centerd learning) merupakan salah satu pendekatan pembelajaran yang lebih menekankan keaktifan siswa di dalam proses pembelajaran, sementara guru hanya berperan sebagai fasilitator. Untuk dapat melaksanakan pembelajaran yang berpusat pada siswa membutuhkan keterampilan guru dalam merancang proses pembelajaran untuk mengembangkan potensi, bakat dan minat yang dimiliki peserta didik. Salah satu pendekatan pembelajaran yang dapat meningkatkan kualitas pembelajaran adalah lesson study. Lesson Study merupakan salah satu upaya untuk meningkatkan proses dan hasil pembelajaran yang dilaksanakan secara kolaboratif dan berkelanjutan oleh sekelompok guru (Rintayati, 2015). Sedangkan Menurut pandangan Hendrayana dalam Supranoto (2015), Lesson Study adalah suatu model pembinaan profesi pendidik melalui pengkajian pembelajaran secara kolaborarif dan berkelanjutan berlandasan prinsip-prinsip kolegalitas dan mutual learning untuk membangun komunitas belajar. Stepanek dalam Zubaidah menjelaskan bahwa lesson study merupakan suatu proses kolaboratif yang dilakukan oleh sekelompok guru untuk mengidentifikasi suatu masalah pembelajaran dan merancang suatu skenario pembelajaran (tahap plan), melaksanakan kegiatan pembelajaran sesuai skenario yang telah dibuat salah seorang guru, sementara guru yang lain mengamati (tahap do), merevisi dan mengevaluasi (tahap see) serta merevisi skenario pembelajaran.

Berdasarkan hasil penelitian yang dilakukan oleh Fauziah, dkk (2017) di salah satu sekolah di aceh besar menyatakan peningkatan motivasi belajar siswa melalui lesson study dikatakan efektif. Dari uraian di atas, rumusan penelitian ini adalah yaitu bagaimana upaya meningkatkan partisipasi aktif siswa dalam pembelajaran virtual melalui implementasi lesson study. Penelitian ini bertujuan untuk meningkatkan partisipasi aktif siswa dalam pembelajaran virtual melalui implementasi lesson study. Manfaat dari penelitian ini bagi siswa adalah dapat meningkatkan kualitas pembelajaran dan kurangnya masalah belajar yang dihadapi oleh siswa.

\section{METODE PENELITIAN}

Pendekatan yang digunakan dalam penelitian ini adalah kualitatif. Moleong dalam Fauziah (2017) menjelaskan pendekatan kualitatif adalah prosedur penelitian yang menghasilkan data deskriptif berupa kata-kata tertulis dan lisan dari orang-orang dan perilaku yang dapat diamati. Jadi penelitian kualitatif adalah penelitian yang mengutamakan proses untuk mengetahui apa yang dialami siswa. Berhubung pada penelitian ini kegiatan pembelajaran dilaksanankan secara daring. Maka yang diteliti disini adalah partisipasi aktif siswa ketika mengikuti pembelajaran yang dilihat dari seringnya siswa bertanya dan merespon pertanyaan guru.

Penelitian ini dilaksanakan di SMP Islam Al falah pada tanggal 18 Agustus - 1 September 2020. Siswa SMP Islam Al Falah kelas VIII.5 semester ganjil tahun pelajaran 2020/2021 yang berjumlah 32 siswa dengan jumlah siswa laki-laki 13 orang dan siswa perempuan 
19 orang. Penelitian ini dilaksanakan pada mata pelajaran IPA kelas VIII pada materi gerak lurus.

Penerapkan Lesson Study untuk meningkatkan partisipasi aktif siswa. Lesson study dilaksanakan sebanyak 2 siklus, dimana satu pertemuan terdiri dari 3 tahap yaitu perencanaan (plan), pelaksanaan (do), dan refleksi (see). Sebelum melaksanakan penelitian, penulis membuat desain pembelajaran terlebih dahulu, kemudian membuat RPP, membuat bahan ajar dalam bentuk PPT karena penelitian ini dilaksanakan pada masa pandemi yang mana pembelajaran nya dilaksanakan secara daring. Setelah itu kami melaksanakan pertemuan online dengan observer 1 orang guru ipa dan 1 dosen fisika untuk tahap pertama yaitu tahap Plan dengan tujuan membahas desain pembelajaran yang akan dilaksanakan. kemudian melaksanakan tahap kedua yaitu tahap do, melaksanakan pembelajaran sesuai dengan desain pembelajaran yang telah dibuat. Pada tahap ini observer hadir untuk mengamati proses pembelajaran dan mengamati partisipasi aktif siswa. Semua proses pembelajaran tersebut direkam dalam bentuk video agar dapat dianalisis. Kemudian dilaksanakan tahap yang ketiga yatu tahap refleksi (see). Pada tahap ini peneliti dan observer melaksanakan pertemuan online lagi untuk membahas refleksi dari kegiatan pembelajaran yang telah dilaksanakan. Di tahap ini membahas kekurangan yang terjadi agar dapat diperbaiki untuk siklus berikutnya. Berikut disajikan diagram alir penelitian yang telah disesuaikan dengan tahapan lesson study (Susanti, dkk. 2018).

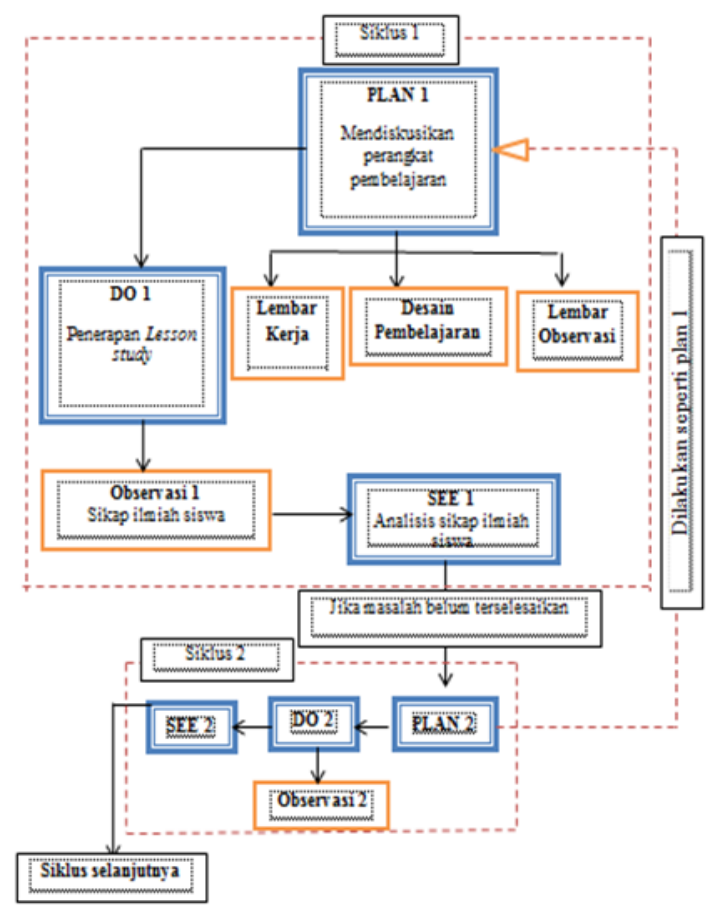

Gambar 1. Skema penelitian lesson study

(Susanti, dkk., 2018)

Data yang digunakan adalah data kualitatif yaitu data keterampilan proses belajar siswa selama pelaksanaan pembelajaran. Pengumpulan data dilakukan dengan menggunakan lembar pengamatan partisipasi aktif siswa selama kegiatan pembelajaran dan dokumentasi selama kegiatan pembelajaran berupa rekaman video.

1. Pengamatan atau observasi

Pengamatan atau observasi adalah proses pengambilan data dalam penelitian menggunakan lembar pengamatan partisipasi aktif siswa. Dalam hal ini penelitian ini dilaksanakan secara virtual, maka observer melihat dan mendengar keseluruhan kegiatan pembelajaran yang dialami siswa dan mengamati bagaimana respon siswa dalam belajar melalui salah satu jaringan belajar.

2. Dokumentasi

Dokumentasi dalam penelitian ini rekaman video dari keseluruhan kegiatan pembelajaran. Rekaman 
video ini digunakan untuk memperkuat data yang diperoleh dan mempermudah menuliskan transkrip pembicaraan guru dan siswa agar dapat diteliti secara keseluruhan.

Lembar pengamatan yang digunakan adalah lembar pengamatan partisipasi aktif siswa yang merujuk pada penelitian yang dilakukan oleh Utama (2016) yang berjudul Peningkatan Partisipasi Aktif Siswa Dalam Pembelajaran Pendidikan Kewarganegaraan Melalui Model Cooperative Learning Tipe Jigsaw Di Kelas V SD Negeri 1 Pedes. Kriteria pengamatan partisipasi aktif siswa ini berdasarkan 2 aspek yaitu aspek fisik dengan 5 indikator dan aspek psikis dengan 2 indikator. Pada penelitian kali ini penulis hanya menggunakan 4 indikator aspek fisik dan 2 indikator aspek psikis. Hal ini dikarenakan sulit untuk mengamati beberapa indikator partisipasi siswa pada pembelajaran virtual.

Tabel 1 Kisi-kisi pengamatan partisipasi

\begin{tabular}{|c|c|c|}
\hline No & Aspek & \\
\hline 1 & Fisik & $\begin{array}{l}\text { 1. } \begin{array}{l}\text { Turut serta dalam } \\
\text { melaksanakan tugas } \\
\text { belajarnya. }\end{array} \\
\text { 2. Bertanya kepada } \\
\text { siswa lain mengenai } \\
\text { hal yang tidak } \\
\text { dimengerti. } \\
\text { 3. Bertanya kepada } \\
\text { guru mengenai hal } \\
\text { yang tidak } \\
\text { dimengerti. } \\
\text { 4. Mengkomunikasikan } \\
\text { hasil pikiran secara } \\
\text { lisan atau } \\
\text { penampilan. }\end{array}$ \\
\hline 2 & Psikis & $\begin{array}{l}\text { 1. } \text { Terlibat } \text { dalam } \\
\text { pemecahan masalah. } \\
\text { 2. } \text { Mencoba } \\
\text { konsep sendiri } \\
\text { diberikan. }\end{array}$ \\
\hline
\end{tabular}

Data yang diperoleh dari hasil pengamatan berupa partisipasi aktif siswa. Data ini kemudian dianalisis untuk mendapatkan persentase dari setiap indikator yang diamati. Trianto dalam Utama (2016) menjelaskan untuk menentukan persentase dari setiap indikator yang diamati dapat dihitung dengan persamaan berikut.

$$
\begin{aligned}
& \text { Persentase (\%) } \\
& =\frac{\text { Skor yang diperoleh }}{\text { Skor maksimal }} \times 100 \%
\end{aligned}
$$

Persentase yang diperoleh dari hasil perhitungan di atas dapat dapat dijabarkan dalam kategori sebagai berikut. Utama dalam Purwanto (2016)

Tabel. Kategori Persentase

\begin{tabular}{|c|c|}
\hline Persentase & Kategori \\
\hline $86-100 \%$ & Sangat Baik \\
\hline $76-85 \%$ & Baik \\
\hline $60-75 \%$ & Cukup \\
\hline $55-59 \%$ & Kurang \\
\hline $0-54 \%$ & Sangat Kurang \\
\hline
\end{tabular}

\section{HASIL DAN PEMBAHASAN}

Hasil penelitian yang telah dilaksanakan mengenai implementasi lesson study sebagai upaya meningkatkan partisipasi aktif siswa dalam pembelajaran virtual.

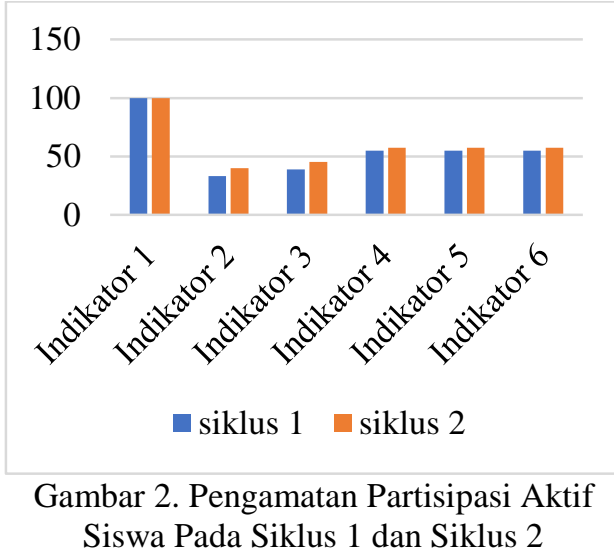

Berdasarkan gambar 2 dapat dilihat bahwa persentase partisipasi siswa mengalami peningkatan untuk setiap indikator. Pada indikator pertama yaitu siswa turut serta dalam melaksanakan tugas belajarnya pada siklus 1 dan siklus 2 tetap $100 \%$. Ini dikarenakan seluruh 
siswa yang bergabung pada pembelajaran virtual mengikuti pembelajaran sampai selesai. Kemudian pada indikator ke dua yaitu bertanya kepada siswa lain mengenai hal yang tidak dimengerti pada siklus 1 dan 2 mengalami peningkatan dari $33.33 \%$ menjadi $40 \%$. Pada indikator ke tiga yaitu bertanya kepada guru mengenai hal yang tidak dimengerti juga mengalami peningkatan dari nilai 39,13 $\%$ pada siklus 1 menjadi 45,33\% pada siklus 2. Kemudian pada indikator ke empat yaitu mengkomunikasikan hasil pikiran secara lisan atau penampilan juga mengalami peningkatan dari 55,07 $\%$ pada siklus 1 menjadi 57,33\% pada siklus 2. Pada indikator ke lima yaitu terlibat dalam pemecahan masalah juga mengalami peningkatan dari 55,07\% menjadi 57,33 \%. Pada indikator ke enam yaitu mencoba sendiri konsep yang diberikan juga mengalami peningkatan dari 55,07 \% menjadi 57,33 $\%$. Hasil penelitian untuk keseluruhan indikator pada siklus 1 data partisipasi siswa memperoleh nilai rata-rata 56,28 $\%$. Sementara pada siklus 2 data partisipasi siswa memperoleh nilai ratarata 59,56\%. Berdasarkan hasil penelitian siklus 1 dan 2 ini menunujukkan ada peningkatan partisipasi aktif siswa. Ada beberapa kendala yang dialami pada penelitian yaitu sulitnya mengamati partisipasi siswa karena pembelajaran dilaksanakan secara virtual. Partisipasi siswa yang teramati hanyalah dari gerak gerik siswa di layar video dan siswa yang banyak bersuara yang disalin ke dalam transkrip pembicaraan siswa dan guru.

\section{KESIMPULAN DAN SARAN}

Berdasarkan penelitian yang telah dilakukan, maka dapat ditarik kesimpulan sebagai berikut:

1. Implementasi lesson study dapat meningkatkan partisipasi aktif siswa dalam pembelajaran virtual
2. Hasil data partisipasi aktif siswa pada siklus 1 memperoleh nilai rata-rata $56,28 \%$. Sementara pada siklus 2 data partisipasi siswa memperoleh nilai rata-rata 59,56\%. Berdasarkan hasil penelitian siklus 1 dan 2 ini menunujukkan ada peningkatan partisipasi aktif siswa Jadi dapat disimpulkan implementasi lesson study dapat meningkatkan partisipasi aktif siswa dalam pembelajaran virtual.

Penelitian ini disarankan untuk dilakukan lebih banyak observasi dalam pembelajaran dikelas. Dilakukan lesson studi berkolaborasi juga dengan kepala sekolah dan tim guru sejawat dengan bidang pelajaran yang sama ataupun berbeda.

\section{DAFTAR PUSTAKA}

Fauziah, dkk. (2017). Upaya meningkatkan motivasi belajar siswa melalui lesson Study di kelas v sd negeri lampagen aceh besar. Jurnal Ilmiah Pendidikan Guru Sekolah Dasar FKIP Unsyiah Volume 2 Nomor 1, 3038.

Imansyah, H. (2021). Konsep dan Prinsip Lesson Study. Diakses tanggal 9 Februari 2021 dari http://file.upi.edu/Direktori/FPMI PA/JUR._PEND._FISIKA/19591 0301986011-

HARUN_IMANSYAH/Sampel_T raining_Workshop/Prinsip_LS.pd $\mathrm{f}$

News. (2021). Pertanyaan dan jawaban terkait Coronavirus. Diakses tanggal 15 Februri 2021 dari https://www.who.int/indonesia/ne ws/novel-coronavirus/qa/qa-forpublic

Zubaidah,Si. (2021). Lesson Study Sebagai Salah Satu Model Pengembangan Profesionalisme Guru. Diakses tanggal 28 Juni 2021 
http://www.researchgate.net/publi cation $/ 318040478$

Rintayati, P. (2015). "Lesson Study Model Pembelajaran Kooperatif Untuk Meningkatkan Kemampuan Inquiry Training Materi Konsep Asam-Basa Pada Mahasiswa Pgsd Fkip Uns." Jurnal Profesi Pendidik 2(1): 5972.

Susanti, N., Fatimah, S., \& Kurniasih, N. (2018). The Learning of Science-Based Laboratory Experiments to Improve the Student's Scientific Attitudes on Optical Materials. Journal of Physics Conference Series, 1-5.
Supranoto, H. (2015). "Penerapan Lesson Study Dalam Meningkatkan Kompetensi Pedagogi Guru Sma Bina Mulya Gadingrejo Tahun Pelajaran 2015/2016." PROMOSI (Jurnal Pendidikan Ekonomi) 3(2):

Utama, M. P. (2016). Peningkatan partisipasi aktif siswa dalam pembelajaran pendidikan kewarganegaraan melalui model cooperative learning tipe jigsaw di kelas V SD Negeri 1 Pedes. Skripsi, tidak dipublikasikan. Universitas Negeri Yogyakarta. 